\title{
PÁJI GrÉTA \\ Kosztolányi „névszemlélete” és névválasztással kapcsolatos eljárásai az újabb kutatások tükrében
}

Kosztolányi Dezső nyelvszemléletével, ${ }^{1}$ valamint nyelvművelő tevékenységével ${ }^{2}$ kapcsolatos elképzelések ismertek a szélesebb tudományos közönség elött, a különböző nyelvészeti és irodalmi tárgyú tanulmányok gyakran idézik szépprózai műveiből vett „neves” szöveghelyeit, illetve az azok kapcsán tett, nevekkel, névadással kapcsolatos nyilatkozatait is. ${ }^{3} \mathrm{Az}$ irodalmi névadással foglalkozó első elméleti jellegű összefoglaló munka, Kovalovszky Miklós hatvankét oldalnyi monográfiája ${ }^{4}$ több mint tíz alkalommal hivatkozik Kosztolányira, vagy idézi szövegeit, így ő a vékonyka könyvben az írói névhasználattal, névadással kapcsolatban legtöbbször felmerülő szerző. Hogy milyen jelentőséget tulajdonított Kosztolányi a névvel kapcsolatos asszociációknak, konnotációknak, arra jól rávilágít akár egyetlen, Kovalovszky által hosszasan idézett, Pesti Hírlapban megjelent cikke is, melyben az író Arany János nevével kapcsolatos benyomásait taglalja. ${ }^{5}$ Szegedy-Maszák Mihály az Édes Anna szövegében felbukkanó tulajdonnevek írói használatát mint a regény „nyelvi megmunkáltságára” utaló „ékes bizonyítékot"6 tárgyalja, a regény kritikai kiadásának a keletkezésről szóló fejezete pedig kiemeli, hogy az író névválasztásai kifejezetten tudatosnak mondhatók, egyes szereplők nevét megváltoztatja a szerző, és a regény tobzódik a „beszédes” nevekben.7

\section{A „névszemlélet” alapjai az életmüben, és egy lehetséges megközelités}

A címben említett „névszemlélet” magától értetődően Kosztolányi nyelvszemléletének szerves részeként értelmezhetô. ${ }^{8}$ Emellett azonban ezeknek a nyilatkozatoknak, illetve a „neves” regény- és novellabeli szövegrészeknek a mennyisége és gyakori idézettsége

\footnotetext{
${ }^{1}$ Szegedy-Maszák Mihály, Kosztolányi Dezső nyelvszemlélete, Alföld, 1994/8, 46-59.

${ }^{2}$ SzILI Katalin, Kosztolányi nyelvmüvelődési tevékenységéröl (Születésének 125. évfordulója kapcsán), Magyar Nyelvőr, 2010/2, 165-182.

${ }^{3}$ Lásd például ÁDÁm Anikó, Kosztolányi a nevekröl, Helikon, 1992/3-4, 389-399.

${ }^{4}$ Kovalovszky Miklós, Az irodalmi névadás, Bp., Magyar Nyelvtudományi Társaság, 1934.

${ }^{5}$ Uo., $12-13$.

${ }^{6}$ Szegredy-Maszák Mihály, Kosztolányi Dezső, Pozsony, Kalligram, 2010, 315.

${ }^{7}$ Veres András, A regény keletkezése = Kosztolányi Dezső, Édes Anna, Kosztolányi Dezső Összes Müvei, Kritikai kiadás, s. a. r. Veres András, Pozsony, Kalligram, 2010, 657-660.

${ }^{8}$ Jelen tanulmányban nem részletezem, de áttekintését lásd Szegedy-Maszák Mihály és Szili Katalin fentebb hivatkozott tanulmányaiban, valamint lásd még Szegedy-MAszák Mihály, Nyelv és nemzet = Sz.-M. M., Kosztolányi Dezső, i. m., 518-547; SzILI Katalin, Kosztolányi a nyelvröl (Kosztolányi nyelvszemléletének kérdéséhez), Magyar Nyelvőr, 2009/1, 14-28.
} 
is kifejezetten indokolttá teszi ennek a jelenségnek az interdiszciplináris megközelítésű, nyelvészeti és irodalomtudományi szempontokat egyaránt érvényesítő vizsgálatát. Mindemellett az ilyen jellegü szövegeknek a gyakorisága hitelesíti a vizsgált jelenségnek - azaz az íói névadásnak és névhasználatnak - a névtan mint önálló tudomány részterületeként felfogható, a jelen tanulmány elkészülésével is igazolható relevanciáját. Az életmű kritikai kiadásának megjelent és készülő kötetei révén hozzáférhetővé válnak az író műveinek egyes szövegváltozatai, a mindenkori olvasóközönség által ismert szövegek elözményei és/vagy - a publikált vagy az első nyilvános megjelenés előtt elvetett - párhuzamai, mintegy megjelenítve az alkotás, a szövegkeletkezés és -alakítás folyamatát. Ez a tény az írói névadás és névhasználat vizsgálatát tekintve is jelentős mérföldkőnek tekinthető, amely révén lehetőség nyílik az egyes névváltozatok összevetésére, valamint egy-egy, az életműben visszatérő név tágabb szövegösszefüggésekben történő értelmezésére.

Rögtön a tanulmány elején indokolt leszögezni, hogy Kosztolányi „sem fordult bizalommal a sarkítottan életrajzi célzatú olvasás felé", ahogyan arra Bengi László is felhívja a figyelmet: „azt a típusú irodalomtörténeti módszertant már legkorábbi írásaitól kezdve határozottan elutasította, amely a mü magyarázatát az író életében vagy az alkotás körülményeiben keresi”." A Hogyan születik a vers és a regény? címü írás kapcsán úgy gondolja, akár „arra is gyanakodhatunk, Kosztolányi csupán játszik, talán a rejtélyt akarja növelni írásai és személye körül, olyan mitikus atmoszférát teremtve, amely az olvasó érdeklődését izgatja".11

Éppen ezért Kosztolányi nevekkel kapcsolatos nyilatkozatai, műveit megemlítő levelei is kritikával kezelendőek, illetve csak közvetetten kapcsolhatóak a művekhez és névválasztásaihoz, hiszen ezek a megnyilvánulások - legyen szó akár egy családtagnak szóló levélről, akár egy újságban közzétett nyilatkozatról -, nem mentesek olykor retorikai stratégiáktól. Ahogyan Bengi az Aranysárkányról tett írói megnyilatkozásokkal kapcsolatban (Indiszkréció az irodalomban; Hogyan születik a vers és a regény?) hangsúlyozza: „[e]gyik vallomás sem tagadja meg élesen az intimitásokra éhes olvasók érdeklődését, de ellenpontozza is azt, amikor a regényíró élményeit másodlagosnak, majdnem esetleges kiindulópontoknak mondja." ${ }^{12}$ Ugyanezt a gondolatkört Szilágyi Zsófia is említi az Aranysárkány kapcsán: „Kosztolányi több ízben erőteljesen hárította az effajta olvasatot [ti. a személyes életével összekapcsolhatót] - máskor meg szinte magára húzta, hiszen tudta, az olvasók szeretik, ha egy író a nyilatkozataiban személyes élményeket, emlékeket tesz az egyes művek mögé."13

\footnotetext{
${ }^{9}$ BengI László, Az önértés viszonylagossága: Az Aranysárkányt olvasó Kosztolányiról = „Visszhangot ver az időben”: Hetven irás Szegedy-Maszák Mihály születésnapjára, szerk. BENGi László, HováNYi Márton, Józan Ildikó, Pozsony, Kalligram, 2013, 328.

${ }^{10}$ Bengi László, Az irodalom önállósága?: Kosztolányi tudományfölfogásáról = B. L., Elbeszélt halál: Kosztolányi-tanulmányok, Bp., Ráció, 2012, 163.

${ }^{11}$ Bengi László, Az Aranysárkány regénye = B. L., Elbeszélt halál, i. m., 91-92.

${ }^{12}$ Bengi, Az önértés viszonylagossága, i. m., 333.

${ }^{13}$ SzILÁGyi Zsófia, Az érettségi mint átmeneti rítus = Sz. Zs., Az éretlen Kosztolányi, Bp., Kalligram, 2017, 132.
} 
Szintúgy óvatosan kezelendő a nevekkel kapcsolatos visszaemlékezések tekintetében Kosztolányi Dezsőné férjéről írott életrajzi regénye, hiszen a szöveg „az írói emlékezéseire való visszatekintéseken, részben talán Kosztolányi saját önéletrajzi följegyzésein, netán Kosztolányi-művek motívumainak önéletrajzi átfordításain"14 is alapulhat. Azonban annyi bizonyos, hogy Kosztolányiné regénye igyekszik valamit visszaadni férje műveinek és nyilatkozatainak nevekkel, névhasználattal kapcsolatos attitüdjéből. A naplójára is támaszkodhatott, ugyanis az alábbi női nevek közül több is felbukkan (egy esetben Kosztolányiné visszaemlékezéséhez képest eltérő utónévvel - lásd: Keserü Etelka - Keserü Zsuzsanna) az 1933-1934-es naplóban: ${ }^{15}$

Névben, minden névben őskori, babonás varázst érzett, és reggelente, ha az újságot kinyitotta, először a halálozás és házasság rovatot nézte, hátha valami különös és érdekes, sokatmondó névre bukkan. A temetőkben is mindig kereste a furcsa neveket. Jegyzőkönyvébe is bejegyezte, beragasztotta a felötlő neveket: „Keserű Zsuzsanna, Lassú Katalin, Kása Ilona, Csecs Böske, Nyers Szidónia, Eper Erzsike."16

Visszakapcsolva az életrajzi célzatú olvasáshoz, az egyértelmüen értett névvel kapcsolatos magyarázatok és azok olvasói „dekódolása” helyett Kosztolányi névszemléletének vizsgálatakor célszerübb az író névadásbeli, nevekkel kapcsolatos, magukban a szövegekben tetten érhető attitüdjeit megvizsgálni, ezeknek a szövegbeli működését tekintve. Többek között azt is figyelembe véve, hogy a névhasználat és a névválasztás milyen írói stratégiákkal társul egy szövegben, ${ }^{17}$ azaz ezeknek milyen típusai körvonalazhatóak a névadás és a névhasználat alapján. Ilyen tekintetben nemcsak a nevek jelentése ${ }^{18}$ és szövegbeli gazdag, poliszémiákon ${ }^{19}$ és hasonló hangalakon alapuló aszszociációinak motívumrendszere, stilisztikai értéke lehet érdekes, hanem azok nyelvi vonatkozású társadalmi-közösségi megnyilvánulása és feldolgozása is. Ilyen az olvasónak az adott névvel és annak használatával kapcsolatos, nyelvközösségileg begyakorolt, konvencionális tudása, azaz, hogy nyelvileg mi mindent jelképez egy név. Kosztolányinak az a módszere, hogy egyaránt számít az olvasó névvel kapcsolatos tudására

\footnotetext{
${ }^{14}$ Bengi, $A z$ irodalom önállósága?, i. m., 137. A regény forrásával, szerzőségével kapcsolatban Bengi László említi: SzIlÁgyi Zsófia, Özvegy, burokban = Sz. Zs., A féllábú ólomkatona: Irodalmi mü-hibák, Pozsony, Kalligram, 2005, 59.

${ }^{15}$ Kosztolányi Dezső, Naplók: 1933-1934 = K. D., Levelek - Naplók, kiad. RÉz Pál, Kelevéz Ágnes, Kovács Ida, Bp., Osiris, 1998, 818, 829, 861.

${ }^{16}$ Kosztolányi Dezsőné, Kosztolányi Dezső, Bp., ASPY Stúdió, 2004, 279. (Eredeti kiadás: Bp., Révai, 1938.)

${ }^{17}$ PÁjI Gréta, Irói névadási tendenciák és stratégiák Kosztolányi Dezső novellái alapján, Névtani Értesítő, 2016, 85-99.

${ }^{18}$ Vö. Szitár Katalin, A prózanyelv Kosztolányinál, Bp., ELTE BTK, 2000.

${ }^{19}$ Vö. Benyovszky Krisztián, Dolce vita Sárszegen: Tolnai Ottónak, Kalligram, 2012/7-8, 32-39.
} 
és egyéni asszociációira. ${ }^{20}$ Így lesz a név egyfajta beszédes nyelvi „sűrítmény”, amelyről a gondolkodás és beszéd többet mond a puszta nyelvhasználatnál, azaz egyebek mellett az író ebben a tekintetben is „társalkotóvá lépteti elö a befogadót”. ${ }^{21}$ Joggal vonatkoztathatjuk ezt az elgondolást a nevekre és „neves” történetelemekre is:

Azok a könyvek, melyek könyvtárad polcain szunnyadnak, még nem készek, vázlatosak, magukban semmi értelmük. Ahhoz, hogy értelmet kapjanak, te kellesz, olvasó. Bármennyire is befejezett remekmüvek, csak utalások vannak bennük, célzások, ákombákomok, melyek pusztán egy másik lélekben ébrednek életre. A könyvet mindig ketten alkotják: az író, aki írta, $\mathrm{s}$ az olvasó, aki olvassa. ${ }^{22}$

Ez a szövegrészlet jól igazolja Szegedy-Maszák Mihálynak azt az állítását, mely szerint Kosztolányi írásaira igen jellemző az a szemlélet, hogy a „prózaírónak nem az a föladata, hogy üzenetet közvetítsen olvasóihoz".23

Nagy valószínűség szerint jól érzékeli Ádám Anikó, amikor Kosztolányi nyelvszemléletéről szólva azt hangsúlyozza, hogy az „ember és a nyelv egyszerre egyedi és társadalmi”, valamint az „egyéni és társadalmi élmények” egymásba játszását említi, ${ }^{24}$ efelől gondolja felderíthetőnek az író nevekkel kapcsolatos elképzeléseit. A szövegben használt nevek és azok adott kontextusban történő hangsúlyozása, valamint a hozzáfüzött, olvasói értelmezésre számot tartó, névre vonatkozó implicit megjegyzések útján válik az olvasó a nevet és annak jelképrendszerét közösségi és egyéni nyelvi szinteken interpretáló befogadóvá. Elég itt csupán a sokat idézett, de a regény szövege által nem kifejtett „neves jelenetre” gondolnunk az Édes Annából: „Amikor például egy reggel véletlenül meghallotta, hogy az urat Kornélnak hívják, érezte, hogy ezen a helyen nem bírja ki sokáig." ${ }^{25}$ Emellett abban a jelenetben, amikor Vizyné tudomást szerez Anna nevéről, benyomásainak narrációbeli kommentálása is mintegy „utalás, célzás” azzal kapcsolatban, hogy a szerző olvasójának hasonló emlékeire, asszociációinak felidézésére számít. Arra tehát, hogy számára is ismerös és gyakori a megidézett szituáció, hogy egy újonnan bemutatkozó személlyel kapcsolatos asszociációinkba a bemutatkozás

\footnotetext{
${ }^{20}$ PÁjI Gréta, Az irói névadásbeli változtatások lehetséges okairól és az olvasói asszociációkról Kosztolányi Dezső szépprózai müvei kapcsán = Félúton 11.: Az ELTE BTK Nyelvtudományi Doktori Iskolájának konferenciája 2015. október 8-9., szerk. Kocsis Zsuzsanna, Krizsai Fruzsina, NÉMETH Luca Anna, megjelenés elött. Valamint hasonló témában lásd még SLíz Mariann, Az irodalmi nevek mint szignálok üzeneteinek kiválasztása = A nevek szemiotikája, szerk. BAuko János, Benyovszky Krisztián, Nyitra - Bp., Nyitrai Konstantin Filozófus Egyetem Közép-európai Tanulmányok Kara - Magyar Szemiotikai Társaság, 2014, 217-226.

${ }^{21}$ Szegedy-Maszák, Kosztolányi Dezső, i. m., 345.

${ }^{22}$ Kosztolányi Dezsö, Ábécé a prózáról és a regényről = K. D., Nyelv és lélek, kiad. Réz Pál, Bp., Osiris, 1999, 443-444.

${ }^{23}$ Szegedy-Maszák, Kosztolányi Dezső, i. m., 519.

${ }^{24}$ ÁDÁM, i. m., 389, 392.

${ }^{25}$ Kosztolányi, Édes Anna, 199.
} 
pillanatában önkéntelenül belejátszanak az általunk ismert azonos nevet viselők tulajdonságai. Emellett a befogadó számára az adott névvel kapcsolatos „jelentés” a névviselők tulajdonságaiból tevődik össze és vonódik el: „- Anna - ismételte Vizyné s a puha, kedves nőnevet rokonszenvesnek találta, mert eddig sohase volt sem Anna nevü cselédje, sem Anna nevü rokona, ami feltétlenül zavarta volna."

Hasonlóan beszédes és szemléletes a névnek mint sokértelmű jelképnek a használata például a Borotva címü szövegben is:

Sokszor egymás után kimondta nevét, halkan, a fal felé fordulva, belesúgta a vízbe, a csapokba, a szobát megtöltötte vele. Nagyon elcsodálkozott, hogy neve is van és hogy épp így hívják, Kasornya Kálmán. Nem valami dallamos vezetéknév, de van benne valami szomorú muzsika. Alapjában véve az is furcsa, hogy néhány betű jelent egy egész embert. Ez a név öt jelenti, fájdalmát, éhségét, testét. ${ }^{27}$

\section{Visszatérö nevek, inter(kon)textuális olvasati lehetöség}

Szilágyi Zsófia is hangsúlyozza Kosztolányi-könyvének bevezetésében, hogy az író szövegeit tekintve „azt látjuk, hogy egyes ötletei (legyenek azok témákat, motívumokat, alakokat érintők) hosszú éveken és szövegek során át csiszolódtak, értelmetlenné téve azt, hogy egy müvet vizsgálva pusztán a közvetlen életrajzi magyarázaton gondolkodjunk". ${ }^{28}$ Kimondottan igaz ez a megállapítás a nevekre is.

Nemcsak a közismert, több szövegben felbukkanó Sárszegre mint helynévre gondolhatunk, amellyel kapcsolatban érdekes példaként merül fel az Oligocén és Eocén, Bácska, majd végül Gőzfürdő címen megjelent szöveg, amelyben a korábbi Szegvár névváltozatot Sárszeggé alakítja Kosztolányi, utólagosan kapcsolva az akkor már megjelent, sárszegi helyszínen játszódó Pacsirtához és Aranysárkányhoz, ${ }^{29}$ mintegy az olvasói elöismeretekre, egyfajta interkontextuális olvasásmódra ${ }^{30}$ tartva számot. Ehhez hasonlóan érdekes visszatérő név például az Anna, mely A rossz orvosban és a Boszorkány című novellában is az Édes Anna egyfajta előzményeként megjelenő „cselédnévként”

\footnotetext{
${ }^{26}$ Uo., 95.

${ }^{27}$ Kosztolányi Dezső, Borotva = Kosztolányi Dezső elbeszélései, kiad. RÉz Pál, Bp., Magyar Helikon, $1965,348$.

${ }^{28}$ SzILÁGyi Zsófia, Bevezetés = Sz. Zs., Azéretlen Kosztolányi, i. m., 13.

${ }^{29}$ Szilágyi Zsófia, Gombhoz a kabátot, címhez a regényt (Alföldi por, Gözfürdö) = Sz. Zs., Az éretlen Kosztolányi, i. m., 148-149. A Sárszeg helynévvel és azok változataival kapcsolatban lásd még HoRvátH Mária, Sárszeg: Adalékok az irodalmi (irói) helynévadáshoz, Magyar Nyelvőr, 1959, 423-428.

${ }^{30}$ Ezzel a témával kapcsolatban vö. SLíz Mariann, Rúth Rhonda és Phil O’Dendron: A névadás szerepe a paródiában = Sokszínü humor: A III. Magyar Interdiszciplináris Humorkonferencia elöadásai, szerk. VArgha Katalin, T. Litovkina Anna, BARTA Zsuzsanna, Bp., Tinta, 81-89.
} 
bukkan fel. A Boszorkányban félelemből és tévedésből gyilkoló cseléd Anna néven jelenik meg, ${ }^{31}$ míg A rossz orvosban a Tirolból érkező Anna nevü lány már kifejezetten „édesannás” tulajdonságokat visel, Vizyné cselédjének mintegy előképeként. Az író a választott névvel mintegy összeköti ezeket a szövegeket:

A gyereken kívül még egyet szeretett: a tisztaságot. Gyülölt minden port és piszkot, üldözte és felkutatta, mint kopó a vadat és bútorok alatt, vagy a pókhálós sarokban, ahova a szemét el szokott bújni - ösztönösen és szenvedélyesen - megsemmisítette. Ilyen vadászat után fáradt volt, de azért tovább dolgozott, ablakokat tisztított, kilincseket és gyertyatartókat fényesített, aztán valami bús, állati kielégüléssel lefeküdt. ${ }^{32}$

Az író névhasználati szokásaihoz, stratégiáihoz kapcsolhatóak a szülők egymás közötti megszólítására használt kifejezések is, melynek a gyermek nézőpontját érvényesítő nyelvi megnyilvánulása $A$ rossz orvoson kívül bővebben kibontva és talán még több olvasói következtetésre lehetőséget adva jelenik meg a Pacsirtában. ${ }^{33} \mathrm{Az}$ alábbiakban A rossz orvos szövegét idézem példaképp, de a Pacsirta második fejezetéből is idézhetö lenne olyan szövegrész, amelyben a narrátor Anya és Apa említőnevet használ Pacsirta szüleiről beszélve: ${ }^{34}$ „A szülők bizonyos idő multán így szoktak beszélni: Anya megy, apa jön. Mire a gyermek megtanulja a nagy szót, hogy »én «, ők elfelejtik és holtuk napjáig csak anyák, apák maradnak, személytelenek." ${ }^{35}$

Van még egy érdekes, a névvel, illetve névtelenséggel kapcsolatos visszatéró írói ötlet, amely a fenti két szöveg párhuzamát erősíti: a „név nélküli” kereskedőtárs motívuma a helyi üzletek nevében. Ez a korábbi, A rossz orvos címú írásban a következőképp jelenik meg:

István az ablakból nézte az utcát, a szembenlevő füszerkereskedést, mely fölé ez volt írva: Kalmár és Társa. Izgalmában arra gondolt, hogy csak Kalmár urat ismeri, aki most is ott állt a boltajtóban, egy zsák fehér szárazbab mellett és hajlongva köszöntötte vevőit. Vajjon ki lehet a társa? ${ }^{36}$

\footnotetext{
${ }^{31}$ Kosztolányi Dezső, Boszorkány = Kosztolányi Dezső elbeszélései, i. m., 11-14.

${ }^{32}$ Kosztolányi Dezső, Béla, a buta; A rossz orvos: kisregények és elbeszélések, Kosztolányi Dezső Összes Művei, Kritikai kiadás, s. a. r. BARTóк István, SÁrкözi Éva, Pozsony, Kalligram, 2015, 127. Az Anna névnek a gyakoriságával kapcsolatban a korszak cselédeinek körében érdekességként lásd HoRváTH László, Egy józsefvárosi bérház női cselédeinek keresztnevei a 19-20. században, Névtani Értesítő, 2016, 79-74.

${ }^{33}$ A párhuzamra Bucsics Katalin hívja föl a figyelmet: Bucsics Katalin, Keletkezéstörténet $=$ KoszToLÁnYI Dezső, Pacsirta, Kosztolányi Dezső összes művei, Kritikai kiadás, s. a. r. Bucsics Katalin, Pozsony, Kalligram, 2013, 726-727. SziLÁgy Zsófia is említi: Az éretlen Kosztolányi, i. m., 197.

${ }^{34}$ Kosztolányi, Pacsirta, 27.

${ }^{35}$ Kosztolányi, Béla, a buta; A rossz orvos, 129.

${ }^{36}$ Uo., 148.
} 
A Pacsirtában ez a névvel kapcsolatos ötlet kissé továbbgondolva, részletezve tér vissza:

- Jöjj velem a városba, - mondta az asszony. Úgyis be kell mennem Weisz és társához. [...] Weisz úr intett a vézna, szomorú alaknak, ki a bolt mélyében üzleti könyvek közé temetve üldögélt, lepkelánggal világított üvegkalitkájában. [...] Ö volt a Társ, az elkallódott, a félreismert, mellözött Tehetség, kinek nevét sem tudta senki és savanyú arcára a gyomorbaj volt írva. ${ }^{37}$

\section{A névteremtés lehetséges ihletforrásai: összeillesztő vagy különválasztó eljárás az alakteremtésben és a névválasztásban}

Az Aranysárkány névadásának ihlető figurái, valamint Kosztolányi különböző nyilatkozatai és alkalmazott retorikai stratégiái, a szövegben használt névteremtő eljárásai tekintetében érdekes Parádi Andrea vizsgálata, amelyet az Aranysárkány egyetlen kéziratlapja kapcsán végzett. ${ }^{38}$ Ezzel összefüggésben érdemes feleleveníteni az író édesanyjának címzett, szintén sokat idézett, 1925. március 30-án kelt levelét, amely az Aranysárkányt is megemlíti: „Olvassátok el ezt a regényemet, melyben egy tanár tragédiáját írtam meg, a lelkem lelkéből. Az alakokban ne keressetek élő személyeket. Öt-hat emberből formáltam egyet, mint az álomban." ${ }^{39}$ Ehhez hasonló némileg az 1927-ben a Nyugatban megjelent Indiszkréció az irodalomban című szöveg alakteremtéssel kapcsolatos, írói műhelytitoknak szánt megnyilvánulása is; igaz, ez már nem próbálja meg távolítani a regényszereplőket valaha élt vagy élő figuráktól:

Mindegyik alakomnak meg tudnám adni a pontos lakáscímét. Gyakran több lakáscímet is, mert némelyik kettőből-háromból van összeróva. [...] Pacsirta annyira közel van a szívemhez, hogy a regény megjelentetése elött - lelkiismeretem nyugtatására - sürgönyöket váltottam hozzátartozóival, $s$ noha ők határozottan lebeszéltek közzétételéről, mégse fogadtam meg tanácsukat; az Aranysárkány minden szereplöje szintén él vagy élt. ${ }^{40}$

Az előbbi idézet a családtagoknak szóló levélbeli útmutatásként értelmezhető az Aranysárkány szereplöivel kapcsolatban: a Pacsirtát mint kulcsregényt olvasó értelmezések és a szerző húgát, Kosztolányi Máriát egyértelműen Pacsirtával azonosító olvasatokat ${ }^{41}$ követő óvatos, az új regény szereplőit érintő megelőző távolításként. A második idézet, ha nem is konkrétumokkal, de igazolni látszik ezt.

\footnotetext{
${ }^{37}$ Kosztolányi, Pacsirta, 193-195.

${ }^{38}$ PARÁDi Andrea, „Egy és más az írásról” az Aranysárkány egy kéziratlapja kapcsán = „Visszhangot ver az idöben", i. m., 319-327.

${ }^{39}$ KosztolánYi, Levelek - Naplók, i. m., 507.

${ }^{40}$ Kosztolányi Dezső, Indiszkréció az irodalomban = K. D., Nyelv és lélek, i. m., 358.

${ }^{41}$ Bucsics, i. m., 712-723.
} 
A már említett vizsgálat azzal a lappal foglalkozik, amely az Aranysárkány kézirategyütteséből a történet tanárainak vázlatos karaktervonásait tartalmazza. Parádi Andrea éppen arra hívja fel a figyelmet, hogy a karakteralkotást tekintve az összeillesztés helyett a szétdarabolás, az egybeolvasztás helyett a különválasztás technikája figyelhető meg. Például a Haverda nevével jelzett karaktervonások végül több szereplő figurájába szóródtak szét ${ }^{42}$ (Haverda a szabadkai gimnázium igazgatója volt Kosztolányi Árpádot megelőzően), de a vázlat több alakja is jelentős átalakítás után került be a regénybe. Hasonlóképpen, Csajkás Tibor figurájának névihletője a Csajkás Mihály nevet viselő tanár volt, míg a karakterek tekintetében talán Novák Antal alakja örizheti leginkább az „életrajzi” Csajkás jellemvonásait. ${ }^{43}$

\section{A kritikai kiadás szövegváltozatai és a szövegkeletkezés közbeni névváltoztatások}

Ahogyan arról már szó esett, az írói névadással foglalkozó vizsgálatok számára is fontosak a Kosztolányi-életmű kritikai kiadása kapcsán hozzáférhetővé vált szövegváltozatok, miként a bennük fellelhető névváltozatok összehasonlíthatósága is. A szövegváltozatok kritikai kiadásban megjelenített rétegei bizonyos mértékig nyomon követhetővé teszik azt a folyamatot, amikor a szerző nevet választ szereplőjének, megváltoztatja azt, esetleg később visszatér hozzá, vagy a név és az alak törlésével a korábbi változathoz képest „kiírja” a szövegből. Természetesen ahogyan az alakteremtés, úgy a névválasztás vagy -változtatás eseteihez sem kell és lehet egyértelmü életrajzi vagy az alkotás folyamatára vonatkozó végleges magyarázatokat kötnünk. Emellett azonban mind a névváltoztatások ténye, mind az alább idézett, névváltoztatással kapcsolatos nyilatkozat visszaad valamit abból, hogy Kosztolányi nagy jelentőséget tulajdonított a nevek akkurátus megválasztásának, azokra mint konvencionalizálódott és képlékenyebb jelentésrétegekkel egyaránt bíró, jelentéses és jelentős stilisztikai hatással rendelkező nyelvi elemekre tekintett. Mindezt a Pesti Hírlap hasábjain olvasható, az írói névadással öszszefüggésben szintén igen gyakorta említett - és Kovalovszky által is idézett - Hogyan születik a vers és a regény? címü szöveg is igazolja, a névválasztás folyamatát némileg misztikus eseménynek tüntetve fel:

Téves azt hinni, hogy a regényíró neveket keresgél nekik, s tetszése szerint ennek vagy annak hívja öket. Csak az életben lehet miniszteri engedéllyel nevet változtatni. A képzelet birodalmában még sohase sikerült. Egyik regényem írása közben felötlött bennem a gyanú, hogy a föszereplő neve a csengésében hasonlít egy ismert emberéhez s esetleg azt a hitet keltheti, mintha rá céloz-

\footnotetext{
${ }^{42}$ PARÁdi, $i$. m., 323

${ }^{43}$ Uo., 324-325.
} 
nék. Elhatároztam, hogy a nevet megváltoztatom. Miután jócskán elörehaladtam, körülbelül száz oldalon kellett visszamenőleg kitörölnöm az eredetileg önként kínálkozó nevet, s egy másikkal helyettesítenem. Erre megbénult a tollam. Hetekig hevert ott kéziratom, anélkül, hogy hozzányúltam volna. Undorodtam tőle. Nem volt kedvem folytatni. Végre cselhez folyamodtam, újra visszaállítottam mind a száz oldalon az eredeti nevet, s akkor megint úgy ment minden, mint a karikacsapás. Közben azzal áltattam magamat, hogy hösömet majd akkor keresztelem más névre, ha kéziratomat nyomdába adom. Természetesen erre se került sor. Ezekkel az álomfigurákkal nem lehet tréfálni. ${ }^{44}$

Igaz, a kritikai kiadás köteteinek szövegváltozatai éppen a nevek közötti keresgélés, a megfelelő név megtalálásának folyamatát világítják meg. Értékeljük bárhogyan is a fenti nyilatkozatot, annyi bizonyos, hogy itt az író is hitelesíti a fönnmaradt kéziratokból kikövetkeztethető - kifejezetten jellemző - névváltoztatás jelenségét.

A legérdekesebb és legszemléletesebb névváltoztatások talán a Pacsirta és az Aranysárkány kéziratában figyelhetőek meg. A Pacsirta esetében fennmaradt kézirat egy viszonylag végleges, piszkozat szintű változat, melynek végső formáját a jól ismert vágásos-ragasztásos módszerrel alkotta meg a szerző. ${ }^{45} \mathrm{~A}$ kritikai kiadás is hangsúlyozza a fennmaradt kézirategyüttes kapcsán (amely tartalmaz elővázlatokat, fogalmazástöredékeket is), hogy a szövegkeletkezés munkafázisainak elkülönítésében komoly fogódzót jelent az egyes személy- és helynevek adott változatainak a szövegbeli használata. ${ }^{46}$ Figyelemre méltó például, hogy a szövegelözmények, szövegváltozatok feltárásában és egymáshoz való viszonyuk megállapításában is segítséget nyújtanak a nevek. Így a Nyugat szövegében egy helyen tévesen - Vajkayné helyett Valkayné változatban - szereplő névalak arra enged következtetni, hogy az 1924-es, Athenaeumnál megjelent $\mathrm{Pa}$ csirta-kötet a Nyugatbeli folytatásos folyóiratközlés szövegére mehet vissza, amelyben ugyanazon a szöveghelyen szerepel a fenti sajtóhiba ${ }^{47}$ A Sárvár-Sárszeg névcsere az egész regényen végigvonult. Bucsics Katalin szerint Kosztolányi egy többé-kevésbé már késznek mondható, sárvári helyszínen játszódó történet megírása után változtatta meg a helynevet Sárszegre. ${ }^{48}$

Az Aranysárkány kritikai kiadásának kézirattal kapcsolatos kísérőtanulmánya is kiemeli, hogy a szövegbeli névváltoztatások egyrészt a szövegrészek elkészültéről szolgáltatnak információt, másrészt a szereplők karakterének alakításáról tanúskodnak. ${ }^{49}$

\footnotetext{
${ }^{44}$ Kosztolány I Dezső, Hogyan születik a vers és a regény? Válasz és vallomás egy kérdésre $=\mathrm{K}$. D., Nyelv és lélek, i. m., 457.

${ }^{45}$ Bucsics Katalin, Szövegforrások és további kiadások = KosztolánYi, Pacsirta, i. m., 614.

${ }^{46}$ Uo., 621.

${ }^{47}$ Uo., 672.

${ }^{48}$ Uo., 623.

${ }^{49}$ PARÁdi Andrea, Kézirat = KosztolánYi Dezső, Aranysárkány, Kosztolányi Dezső Összes Művei, Kritikai kiadás, s. a. r. Bengi László, PARÁdi Andrea, Pozsony, Kalligram, 2014, 1036-1037.
} 
Érdekesség, hogy a kézirat tanúsága szerint az Aranysárkány sem Sárszegen játszódott eredetileg, ${ }^{50}$ csak a későbbi módosítások során lett ez a helyszín neve, megidézve a korábbi regényt, a Pacsirtát, s ezáltal interkontextuális kapcsolatot hozva létre a két szöveg között.

$\mathrm{Az}$ egyik legérdekesebb, többlépcsősnek nevezhető névváltoztatás az Aranysárkány Pepikeként ismert szereplöjének, Novák Antal unokanővérének a nevét érintette. A korai fogalmazványokban még a Karolin név szerepel, a szedőpéldányban, a kézirat tisztázásakor viszont már Jozefinre javította Kosztolányi a nevet, ${ }^{51}$ de ugyanitt felbukkant a Lujzi névváltozat is; végül Pepike lett a figura megnevezése. Ahogyan arról már korábban is szó volt, az életrajzi jellegü „nyomok” mellett a nevek azonosságából sem indokolt messzemenő vagy egyértelmü következtetéseket levonni: ugyanakkor Bengi László a korábbi névváltozat miatt felhívja a figyelmet arra, hogy Pepike figurájának megalkotásában akár Kosztolányi anyjának barátnője, Wéber Jozefina karaktere is közrejátszhatott. ${ }^{52}$

Az említetteken kívül még számos kisebb vagy „egylépcsős” névváltoztatás figyelhető meg a kritikai kiadás szövegváltozataiban és a kísérő tanulmányok összegző táblázataiban, amelyek mind alátámasztják Kosztolányi névválasztással kapcsolatos mügondját, a történetek nyelvi megalkotottságának a nevek szintjén is kiemelten tükröződő szerepét.

Érdekesség, hogy például Novák Hilda neve nem változik meg a regény folyamán, ami mintha azt látszana igazolni, hogy a nevével együtt mintegy „kész” alakként lép be a regénybe. Ezt támasztaná alá Kosztolányiné azon kijelentése, mely Novák Hilda alakját Lányi Heddával mint ihletforrással hozza összefüggésbe. ${ }^{53}$ Ezt igazolhatja a két név hasonló hangalakja, de ugyanez értelmezhető egyúttal távolító gesztusként is: amenynyiben hitelt adunk a fenti feltételezésnek, nem a felismerhetőségig hasonló vagy a feltételezett ihlető személy nevével teljesen azonos nevet ad szereplőjének Kosztolányi, csak a szótagszámot és a kezdőbetűt megőrzőt. Szintén ezt az ihletforrást erősíti Kosztolányinak Csáth Gézához írt, Bengi 2012-es tanulmánykötetében teljes terjedelmében közölt levele 1910-ből, melyben az író a Heddával való szakítást és ennek előzményeit tárgyalja. ${ }^{54} \mathrm{~A}$ konkrét és kizárólagos életrajzi magyarázat keresését mellőzve is érdekesség továbbá a Hedda-Hilda párhuzamhoz kapcsolódva, hogy a fent említett levélhez képest később keletkezett, Hogyan születik a vers és a regény? című szövegre emlékeztető, a Hilda nevet említő Indiszkréció az irodalomban-részlet milyen viszonyban lehet a regény névválasztásával, keletkezéstörténetével, esetleg csak példaképp említi ezt a nevet a szerző:

\footnotetext{
${ }^{50}$ Bengi László, Keletkezéstörténet = KoszToLÁnyi, Aranysárkány, i. m., 1093.

${ }^{51}$ PARÁdi, Kézirat, i. m., 1037.

${ }^{52}$ Bengi László, Motívum és hatás = B. L., Elbeszélt halál, i. m., 150-151.

${ }^{53}$ KosztolánYi Dezsőné, Kosztolányi Dezső, i. m., 256.

${ }^{54}$ Bengi, Motívum és hatás, i. m., 143-145.
} 
Emlékezem, egyszer írás közben tudatára ocsúdtam, hogy az a regényalak, akit mintáztam, régi ismerősöm, s csodálkozva vettem észre, hogy az ő kedves nevén nevezem. Ez ízlésem ellen való volt. Szeméremből, tapintatból megváltoztattam a nevét, a kéziratban visszamenőleg kihúztam mindenütt, mással próbáltam helyettesíteni. Másnap reggel egy betüt se tudtam írni. Aki Hilda, az maradjon Hilda. Ha Jolánnak keresztelem át, tollam elakad. ${ }^{55}$

\section{A nevek jelentőségének nyoma Kosztolányi levelezésében}

A nevek fontosságát jelzi nemcsak az életműben, hanem az író gondolkodásmódjában is, hogy a névvel kapcsolatos megjegyzések Kosztolányi levelezésében is tetten érhetőek. A regényekkel, szereplőkkel kapcsolatban tett nyilatkozatokhoz képest ebben az esetben az lehet a különbség, hogy a magánlevelekben talán öszintébben nyilvánulhat meg a névhez füződő elemi viszony, és kevesebb retorikai stratégiával kell számolnunk, mint a regényekkel, illetve azok névválasztásával foglalkozó írásokban. (Kivételként kezelendő a családnak szóló, fentebb már említett „útmutató” az Aranysárkány szereplőiről.)

A nevekkel kapcsolatban érdekes, de hétköznapinak mondható a korai levelezésből az a példa, amikor a Jövendő című folyóirat név nélkül közli Kosztolányi versét. Ezt több ízben nehezményezi Csáthnak írott, egyre türelmetlenebb hangvételü leveleiben is: ${ }^{56}$ természetesnek tekinthető, hogy a fiatal, még pályája elején álló szerző ragaszkodik neve feltüntetéséhez a folyóiratban.

Különösen szemléletes Kosztolányinak a levelezésből is előtűnő névszemléletét és nevekhez való viszonyát illetően a Babits Mihálynak 1907 decemberében írott levél. Ebben tájékoztatja a költőt versének a Népszava karácsonyi mellékletében, név nélkül történő megjelenéséről, és egy Csáth Gézával együtt kitalált álnevet javasol Babitsnak:

Kívánságod szerint nem tettem alá a nevedet. Ellenben én és Csáth Géza hosszas tanakodás után egy az egyéniségedet és költői fizionómiádat jellemző nevet adtunk neked: a Deér Dénest. Ez arisztokratikus, szójátszó, amellett eltagadhatatlanul sovány név. Meg vagy elégedve irodalmi keresztapáiddal? [...] Igazán szeretném, ha valahogy elhagynád odúdat, és a Deér Dénes névvel meghódítanád szegény országunkat. ${ }^{57}$

Szintén tartalmaz az írói álnévadással kapcsolatos gondolatokat Kosztolányi 1924 augusztusában édesapjához írott levele, melyben engedelmét kéri, hogy az idősebb Kosztolányi Árpád által talált Vén Sas név helyett mást ajánlva ő adjon neki írói álnevet:

\footnotetext{
${ }^{55}$ Kosztolányi, Indiszkréció az irodalomban, i. m., 357.

${ }^{56}$ KoszTolányi, Levelek - Naplók, i. m., 48-50.

${ }^{57}$ Uo., 136.
} 
„Engedd meg, hogy irodalmi keresztapád legyek. Te annak idején nekem adtál nevet, most én adok neked." 58

Érdekes lehet még a korai levelezésből például az 1907 május végén Ady Endrének írott levél, amelyben a költő nevével kapcsolatos személyes asszociációjáról is ír a fiatal Kosztolányi: „Az ön nevének hangzása - bocsássa meg ezt a gyerekes naivságot - mindig úgy hatott rám, mint valami fehérség, valami kékesen csillogó tisztaság. ${ }^{\prime 59} \mathrm{Ez}$ a levélrészlet némileg megidézi a Pesti Hírlapban Arany János neve kapcsán tett jóval későbbi, már említett nyilatkozatot.

\section{Kosztolányiné életrajzi regénye mint az író névszemléletének visszatükrözöje}

Mint már említettem, Kosztolányi Dezsőné férjéről írott regényes életrajza nem is a megírt adatok és emlékek pontosságában és hitelességében, hanem inkább abban a tekintetben figyelemre méltó - és azzal tükrözi Kosztolányi névszemléletét -, hogy igazolja: valóban fontos volt az író számára a nevek megválasztása. A névvel kapcsolatos szövegrészekben nyelvileg is mintha Kosztolányi hangja, szemléletmódja köszönne vissza. Igaz, jelentéssel kapcsolatos névmagyarázatot nemigen találni Kosztolányinál, de mintha a nevek életműbeli fontossága indokolná rögtön az életrajz elején, hogy a feleség megadja a Desiderius név jelentését, és kicsivel később a Kosztolányi név latin és szlovák etimológiáját, ${ }^{60}$ majd fejezetekkel később az édesanya, Eulália nevének jelentését is. ${ }^{61}$

Szintén az álnévadáshoz, az „irodalmi keresztapasághoz” köthető a müből talán leginkább ismert, névvel kapcsolatos gesztus, hogy Kosztolányi Dezsőné a Görög Ilona írói álnevet férjétől kapta: „Átnézi fordításomat, kijavítja, ő választja számomra a Görög Ilona nevet is, azt mondja, olyan szép, gömbölyü név, illik hozzám. Igazi nevemet, a Harmos nevet nem szereti. - Semmi értelme - mondja." ${ }^{62}$

Esti Kornél nevével kapcsolatban nem találni olyan szerzői magyarázatot, fejtegetést, mint az Édes Anna név vagy a többi regény szereplőinek ihletforrása kapcsán tett nyilatkozatok. Érdekes azonban, hogy maga Kosztolányiné megpróbálja megmagyarázni a név eredetét az életmüben. A magyarázat Kosztolányi modorában történik, az Indiszkréció az irodalomban és a Hogyan születik a vers és a regény? kulisszatitkait idézve meg nyelvileg, talán hasonló célzattal, mint ahogyan az említett szövegek is készülhettek - a szépirodalmi szövegeket ismerő olvasók érdeklődésének megnyerésére és fenntartására:

\footnotetext{
${ }^{58}$ Uo., 500.

${ }^{59}$ Uo., 125.

${ }^{60}$ Kosztolányi Dezsőné, Kosztolányi Dezső, i. m., 7-9.

${ }^{61}$ Uo., 114.

${ }^{62}$ Uo., 204.
} 
Esti Kornél? Hogy hogyan támadt ez a név? Igazán magam sem tudnám megmondani. Talán a pesti polgár alakjából, aki derűs, világos, egyszerü, mint a nappal, de baljós és kétes, akár az este, keresztneve Kornél, tehát polgár, akár Vizy Kornél, Édes Anna Vizy Kornélja, de sokkal-sokkal bonyolultabb és veszélyes, furcsán ön- és közveszélyes, kissé az elmebaj határán, irracionális, mint maga az emberi élet. Tetszett neki ez a név, de sohasem elemezte keletkezését. ${ }^{63}$

\section{Összegzés}

A fentiek alapján látható, hogy Kosztolányi esetében indokolt az írói névadás és az ennek alapjául szolgáló „névszemlélet” vizsgálata, hiszen kimondottan a „névérzékeny” ${ }^{4}$ írók körébe sorolható. Jelen tanulmány azt igazolja, hogy a minél teljesebb összkép érdekében célravezető a témát egyidejüleg nyelvészeti és irodalomtudományos szempontokkal, interdiszciplináris kiindulópontból megközelíteni. A fentiekből kiderül, hogy ennek eredményeképpen milyen „névszemlélet” rajzolható meg Kosztolányi Dezső névvel kapcsolatos nyilatkozataiból, írásaiból, illetve ez a szemlélet miképp tükröződik szépprózai szövegeiben, és hogyan harmonizál a nyelvvel kapcsolatos elgondolásaival. A tanulmány szemléletes példákat hoz az idevágó fontosabb, „neves” szöveghelyekről, ugyanakkor a nevekkel kapcsolatos szöveggyüjtemény mellé rövid értelmezést is ad az író névadási eljárásairól, stratégiáiról, melyet részletesen egy korábbi tanulmányomban elemeztem. Amint láthattuk, az életmű kritikai kiadásának már megjelent és készülő kötetei kiemelkedő fontosságúak a Kosztolányi írói névadásával kapcsolatos újabb kutatásokban. Ezek a kötetek a szövegváltozatok közlése révén összehasonlíthatóvá és láthatóvá teszik az esetleges és nem is oly ritka névváltoztatásokat, megvilágítják a megfelelő név megtalálásának eseményét a szövegkeletkezés folyamatában.

\section{GRÉTA PÁJI \\ Kosztolányis "Naming Practices" and Name-Related Procedures in the Light of Recent Research}

Based on the above claims it can be concluded that the research of Kosztolányis literary onomastics and "naming practices" is justified by the fact that he is often regarded as one of the "name-sensitive" authors. This paper demonstrates that an interdisciplinary approach to this question, which combines both linguistic and literary aspects, proves

\footnotetext{
${ }^{63}$ Uo., 279.

${ }^{64}$ G. PAPP Katalin, „én Alsórácegresből vagyok...”: Irói névadás Lázár Ervin müveiben, Doktori $(\mathrm{PhD})$ értekezés, Bp., ELTE BTK, 2009. http://doktori.btk.elte.hu/lingv/gecseysandornepappkatalin/diss.pdf (Letöltés ideje: 2017. december 12.)
} 
to be highly effective in creating a detailed overview of the topic. The study sheds light on the "naming practices" which can be deducted from Dezső Kosztolányi’s statements and writings related to naming and on how these approaches are reflected in his prose and harmonise with his views of language. The study provides illustrative examples from the most important and relevant name-related texts and at the same time gives a brief explanation of the author's naming procedures and strategies, which I analysed in detail in a previous study. As we have seen, both the published and announced volumes of the lifework's critical edition are of crucial importance for future research in the author's literary onomastics. These volumes make it possible to compare and visualise the eventual and not-so-rare name changes and the path to finding the right name during the creation of the text. 